\title{
外来化学療法患者の疼痛管理における薬荗師介入とその評価
}

\author{
奥田泰考*，中澤寛仁，須藤俊明 \\ 自治医科大学附属病院薬剤部
}

\section{Pharmacist Intervention in the Pain Control of Outpatients Receiving Chemotherapy and the Evaluation}

\author{
Yasunari Okuda*, Tomohito Nakazawa and Toshiaki Sudoh \\ Department of Pharmacy Jichi Medical University Hospital \\ $\left[\begin{array}{l}\text { Received June 7, } 2011 \\ \text { Accepted November 30, } 2011\end{array}\right)$
}

The number of cancer patients has been constantly rising, and it is difficult to make them understand how to use opioids within a limited time for ambulatory care. As a result, there are cases of inadequate pain control and deterioration in adherence to medication due to adverse effects.

With the goal of improving various problems in symptom relief for cancer patients, pharmacists of a palliative care team of the Pharmaceutical Department in Jichi Medical University Hospital launched their involvement in explaining opioid introduction and pain control for outpatients receiving chemotherapy. Pain assessment was conducted using a Numeric Rating Scale.

There were 32 cases of initial instructions for opioid introduction, 86 cases of ongoing assessment of pain/side effect, 42 cases of telephone support after the patient returned home, 49 cases of involvement in pain-killer prescription, and 27 cases of inadequate drug adherence.

In research on NRS at the initiation of involvement in pain management as well as at the end of chemotherapy in 84 patients whose treatment was shifted to palliative-based therapy, verification of the results by Wilcoxon $t$-test $(p<0.01)$ showed a significant reduction in pain.

The significant reduction in NRS shows that pharmacists of palliative care teams with experience of pain management are able to perform appropriate patient education and pain management by being involved from the stage of opioid introduction in outpatients receiving cancer chemotherapy.

Key words — opioid introduction, pain control, outpatients receiving chemotherapy, Numeric Rating Scale

\section{緒言}

近年分子標的薬をはじめとした多くの抗がん剂 の開発に伴い, がん化学療法の治療レジメンは大 きく進歩している。 その結果，延命を目的とした 二次治療以降の選択肢が広がり，治療期間が長期 化している。さらに, がん化学療法の副作用に対 する支持薬剤の開発により，患者の quality of life （以下，QOL と略す）を考慮した外来通院での化 学療法が可能になってきた。
一方，抗がん剤治療を受けている患者の 3 分の 1 に疼痛が生じているとの報告 ${ }^{1)}$ があり, 外来化 学療法中においても疼痛コントロールを開始しな ければならない。

しかし，がん患者は増加傾向にあり（国立がん 研究センターがん対策情報センター部位別がん粗 罹患率の推移 http://ganjoho.jp ), 外来診療の短い 時間の中でオピオイドに対する誤解を解き, 適正 なオピオイドの使用方法を患者に理解させること は非常に困難な状況になってきている. その結果,

*栃木県下野市薬師寺3311-1 
地域医療におけるがん疼痛管理においてオピオイ ドが投与されているのにもかかわらず, 痛みが緩 和することなく, 副作用が発現している患者が多 い実態にある ${ }^{2}$.

WHO における緩和ケアの定義および 2004 年 4 月から施行されたがん対策基本法に扔いて早期の 緩和ケアが推奨されている. 加えて, 早期の緩和 ケア介入によりがん患者の予後が延長するとの報 告が挙げられた ${ }^{3)}$ 。これらの背景から, 薬剤師に おいても積極的に症状緩和に取り組み，より早期 からの緩和ケアに参画しなくてはならないと考え る.

自治医科大学附属病院（以下, 当院と略す）で は, 緩和ケアチームに所属している薬剤師が, が ん患者の症状緩和に扔ける問題点の改善と早期緩 和ケアの提供を目的に, 平成 22 年 1 月から外来 化学療法患者を対象にオピオイド導入指導および その後の疼痛管理への関与を開始した。本稿では その取り組みと評価について報告する.

\section{方法}

\section{1. 対象患者}

平成 22 年 $1 \sim 12$ 月の 1 年間において, 当院臨 床腫瘍科を受診し外来化学療法を受けている患者 を対象とした。

\section{2. 業務手順}

業務手順の概要を図 1 に示す.

\section{3. オピオイド導入指導}

オピオイド導入指導として患者に対し疼痛状況 の聞き取りを行い, 服薬指導, 疼痛評価, 鎮痛薬 の処方設計, 副作用への処方提案を行った。

服薬指導に要する時間の短縮, 指導薬荗師の変 更による疼痛評価や服薬指導項目のばらつきを少 なくすることを目的に OPTIM（「緩和ケア普及の ための地域プロジェクト：OPTIM study（厚生労 働科学研究 がん対策のための戦略研究)」) の疼

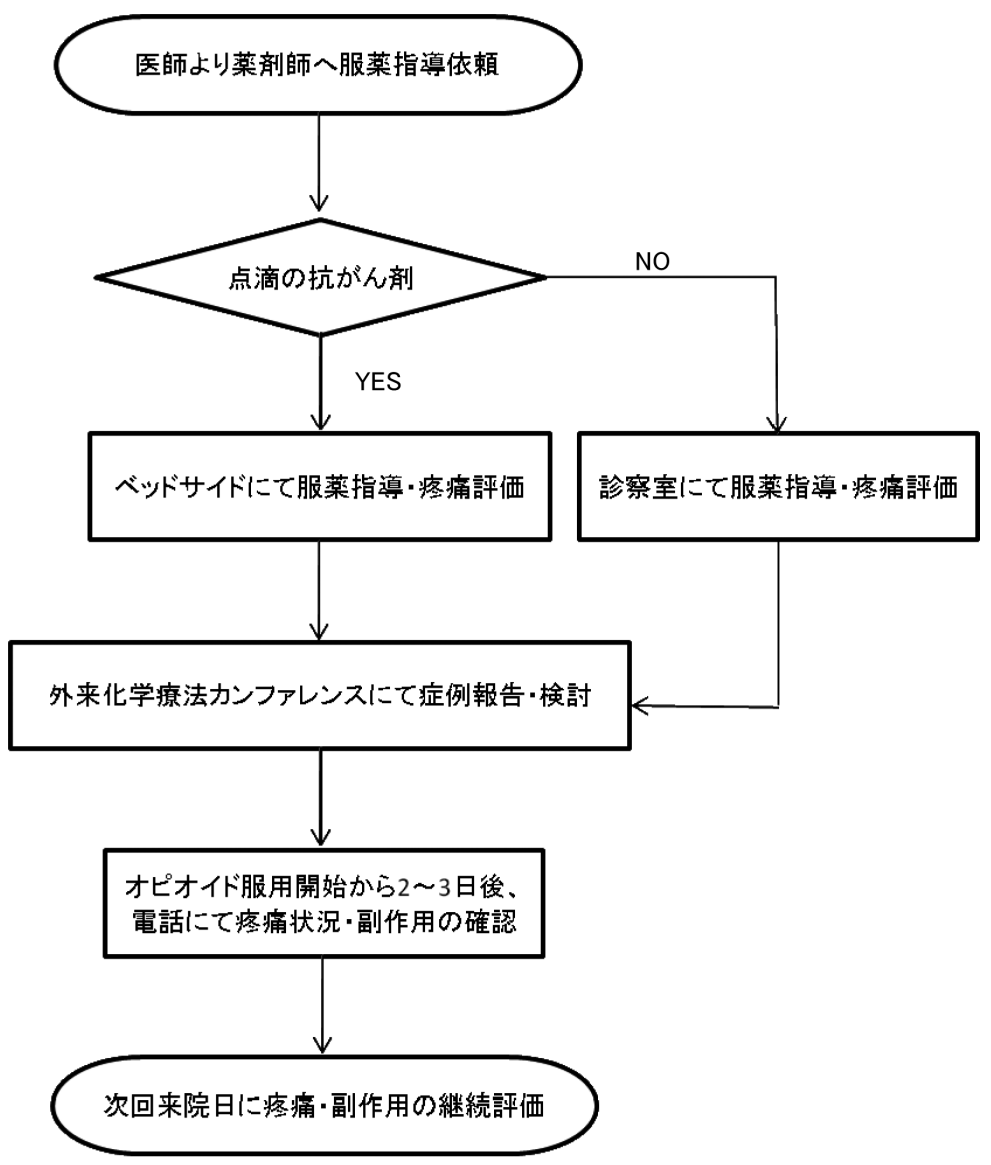

図 1 オピオイド導入指導から継続評価までの業務フローシート 
痛評価シート（図 2）を利用した。

疼痛評価は numeric rating scale（以下, NRS と 略す）を使用し，オピオイド導入前後および投与 量変更前後および外来化学療法による治療終了時 に評価を行った。

\section{4. 継続的な疼痛管理}

オピオイド導入後, 継続的な疼痛管理に関与す ることを目的に2つの業務を開始した。

1 点目として, オピオイド導入やオピオイド ローテーション時における患者帰宅後の疼痛管理 支援を開始した。患者の同意を得て電話を用いた 服薬状況および効果・副作用の確認を行い, 訴え に応じた服薬のアドバイスや症状への対処法の指
導を行った. 電話を用いた患者支援の実施日は， 副作用の発現時期をオピオイドの薬物動態から血 中濃度が定常状態に達する時間を換算し, オピオ イド服用開始後 $2 \cdot 3$ 日を目安とした。

2 点目として, 次回来院時にオピオイドをはじ めとした鎮痛薬の効果の確認やレスキュー薬の使 用状況, 副作用の出現状況, 服薬アドヒアランス の確認を行い, 疼痛状況に応じてオピオイド投与 量の変更，オピオイドローテーション，副作用へ の処方提案を医師に行った.

\section{5. 疼痛管理への薬剤師介入の評価}

疼痛管理への薬剂師介入の評価として NRS の 経時的な変化が評価指標の 1 つになると考え, 統

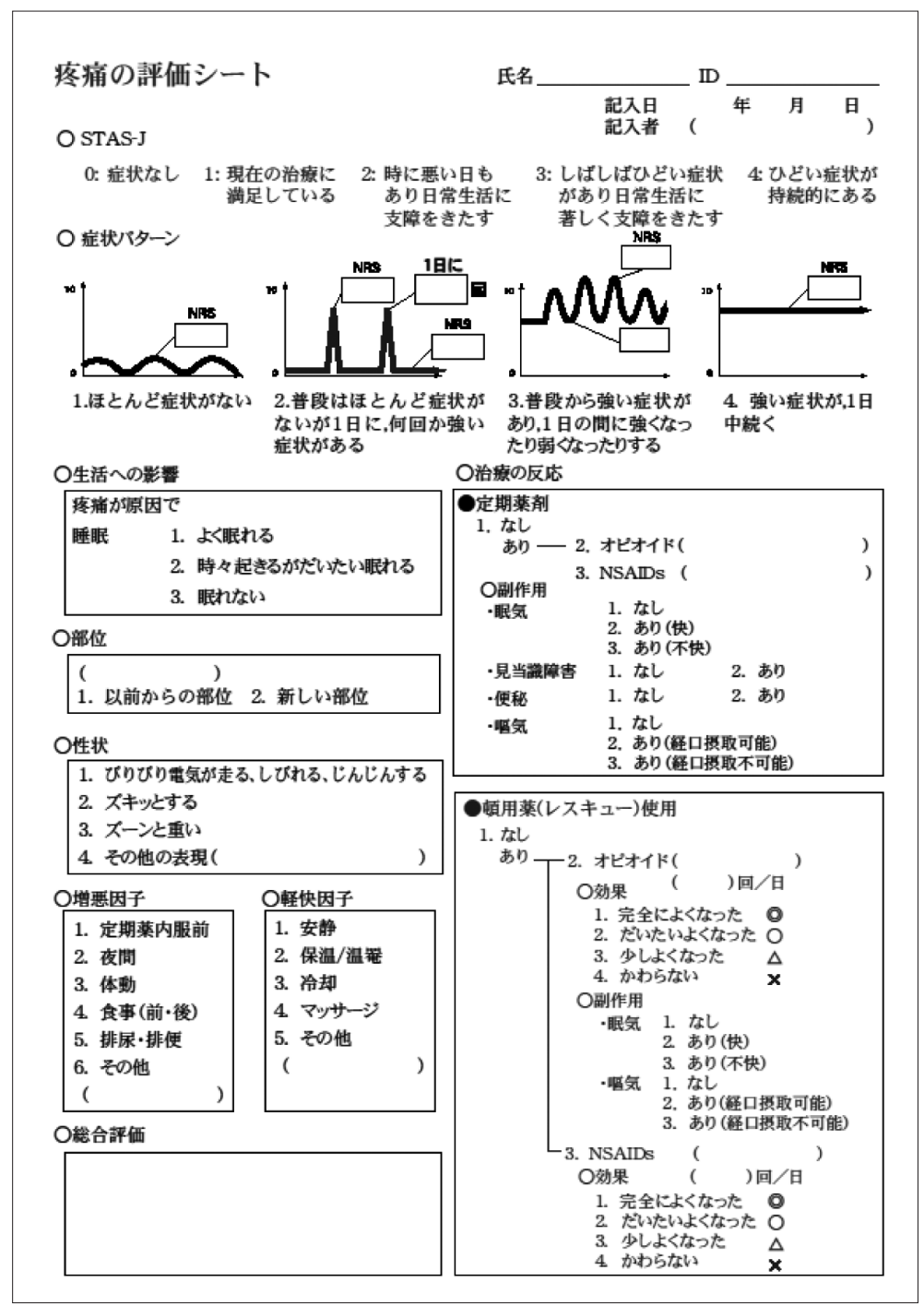

図 2 OPTIM（「緩和ケア普及のための地域プロジェクト：OPTIM study（厚生 労働科学研究 がん対策のための戦略研究)」）の疼痛評価シート 
計的な検討を行った. NRS は Wilcoxon $t$-test を用 いて検定し，有意水準を $5 \%$ とした。

\section{結果}

\section{1. 業務件数の推移とその内訳}

業務件数の推移とその内訳を図 3 に示す．時 間の経過に伴い実施件数は増加し, 1 年間の総件 数は 194 件であった．実施内容の内訳はオピオイ ドの導入指導が 32 件, 疼痛 /副作用の継続評価 が 86 件, 鎮痛薬処方設計 (投与量・薬剂変更提案) が 49 件, 服薬アドヒアランス不良症例への関与 が 27 件であった.

\section{2. 追加処方提案}

薬剂師が患者と面談後, 医師に追加処方薬を提
案した件数は 58 件であった. 薬効別に検討する と緩下剂が 21 件 (36\%), 制吐剂が 13 件 (22\%), 非オピオイド製剂 7 件 (12\%)，オピオイドレス キュー製郕 11 件 (19\%), 鎮痛補助剤 3 件 $(5 \%)$, その他 3 件 (5\%) であった。 また, 薬郕師の関 与当初 $70 \%$ 以上の処方に扮いて追加薬剂の提案 を行っていたが, 5 力月を経過後, 急激に薬剤提 案を行った処方の割合が減少していた（図4）。

\section{3. 服薬アドヒアランス不良患者の要因}

服薬アドヒアランス不良の要因を大別すると理 解不十分 7 例，拒薬 20 例であった。 その細かな 内訳を図 5 にまとめた.

\section{4. 電話を用いた患者帰宅後の疼痛管理支援}

患者帰宅後の疼痛管理支援として, 電話を用い

件

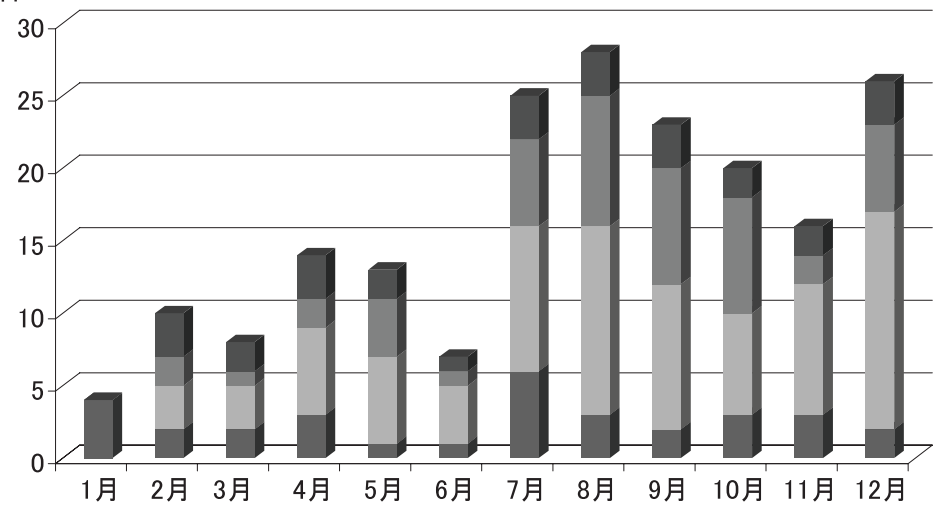

ロ服薬アドヒアランス改善指導

-鎮痛薬処方設計(投与量 $\cdot$ 薬剂 変更提案)

疼痛/副作用の継続評価

図 3 業務件数の推移とその内訳

\section{ロオピオイド導入指導}

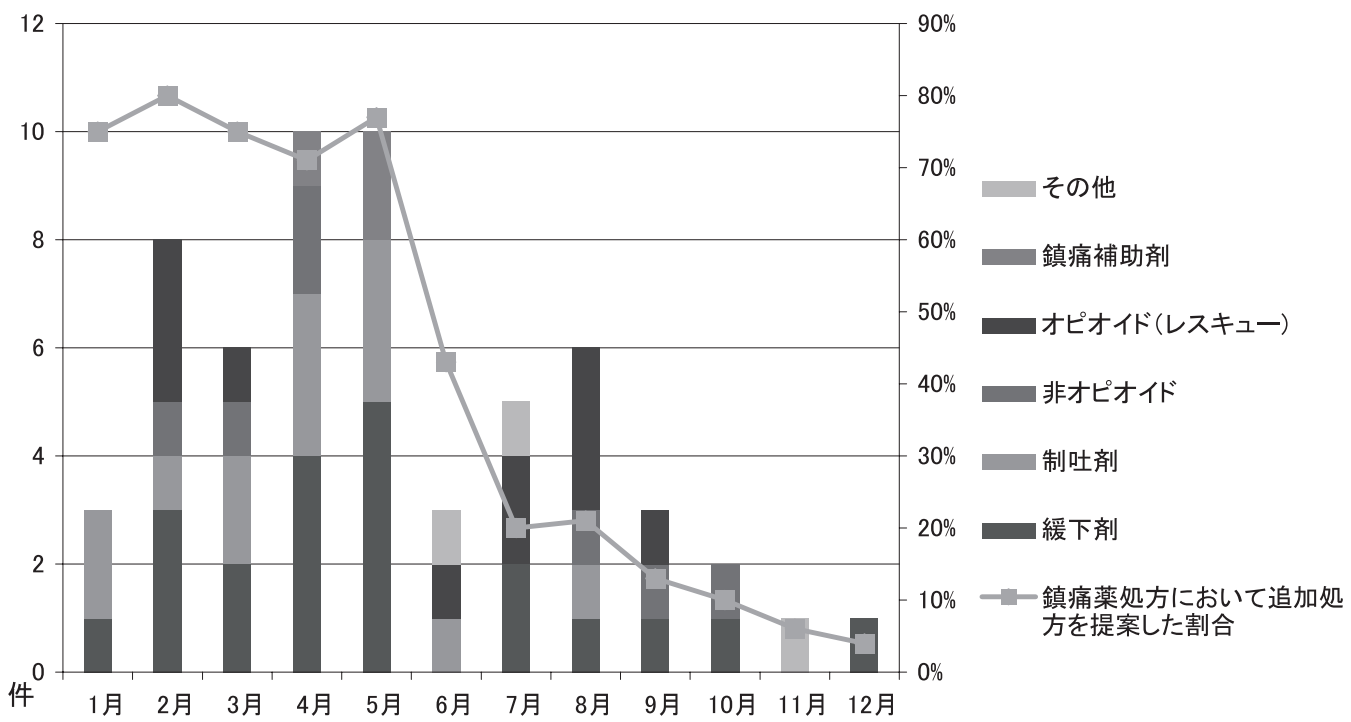

図 4 鎮痛薬処方に扔いて追加処方を提案した割合とその薬効別内訳 
た服薬状況および鎮痛薬の効果・副作用の確認を 行った。電話を用いた疼痛管理支援は調查期間中 42 件あり，患者の受け入れは $100 \%$ あっった．訴 えが多かった症状として眠気 13 件 (31\%)，便 秘 8 件（19\%）であった（図6）.

\section{NRS の変動と統計評価}

期間中，緩和医療中心に移行した 84 人の患者 において，オピオイド導入時の NRS と外来化学 療法による治療終了時の NRS を図 7 に示す. NRS 值変動の差は平均で 3.04, Wilcoxon $t$-test 用いた検定の結果は $p<0.01$ となり, 疼痛は統計 学的に有意に減少していた。

\section{考察}

今回の調査結果に基づき, 外来化学療法患者の 疼痛管理における薬剂師介入の評価を患者拈よび 医療スタッフの両面から検討を行った。

患者に対しての評価は，患者の主観的な疼痛強 度を客観的に判断できるNRS を指標とし検討を 行った. 今回の調查に扔いて, オピオイド導入時 と外来化学療法による治療終了時の NRS を比較 したところ有意に減少をしていた。この結果に基 づき，薬剤師介入により外来化学療法期間中にお いて，効果的な疼痛管理を行えたと考える。 その 要因として $2 つ の$ 取り組みが関連していると推察 できる. 1 点目として患者帰宅後の疼痛管理支援

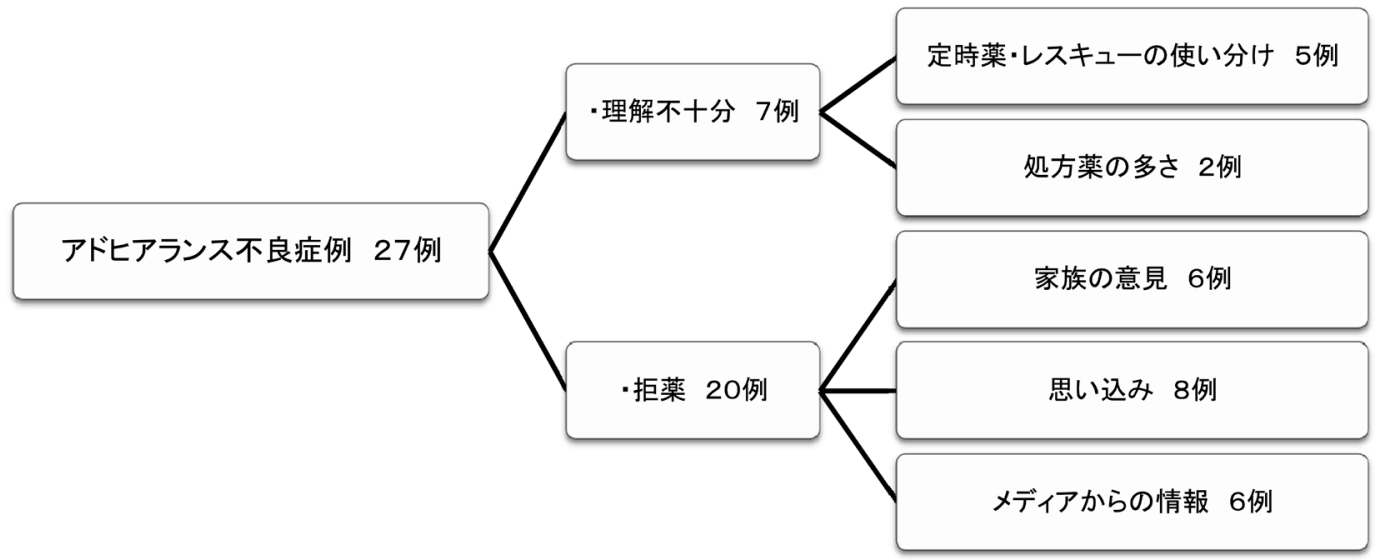

図 5 服薬アドヒアランス不良の要因

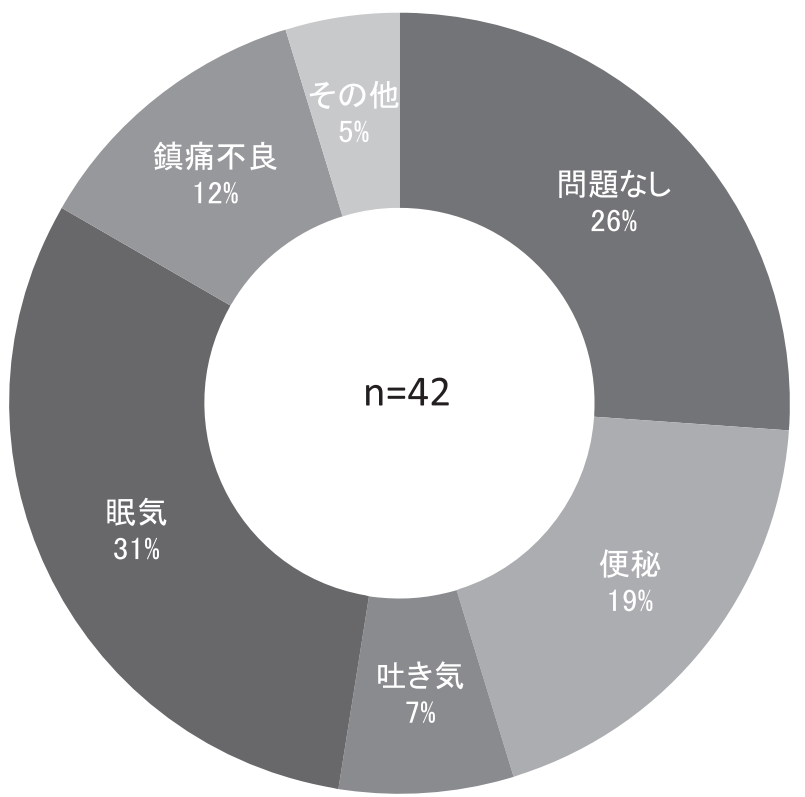

図 6 電話を用いた患者支援で聴取した患者帰宅後の訴え 


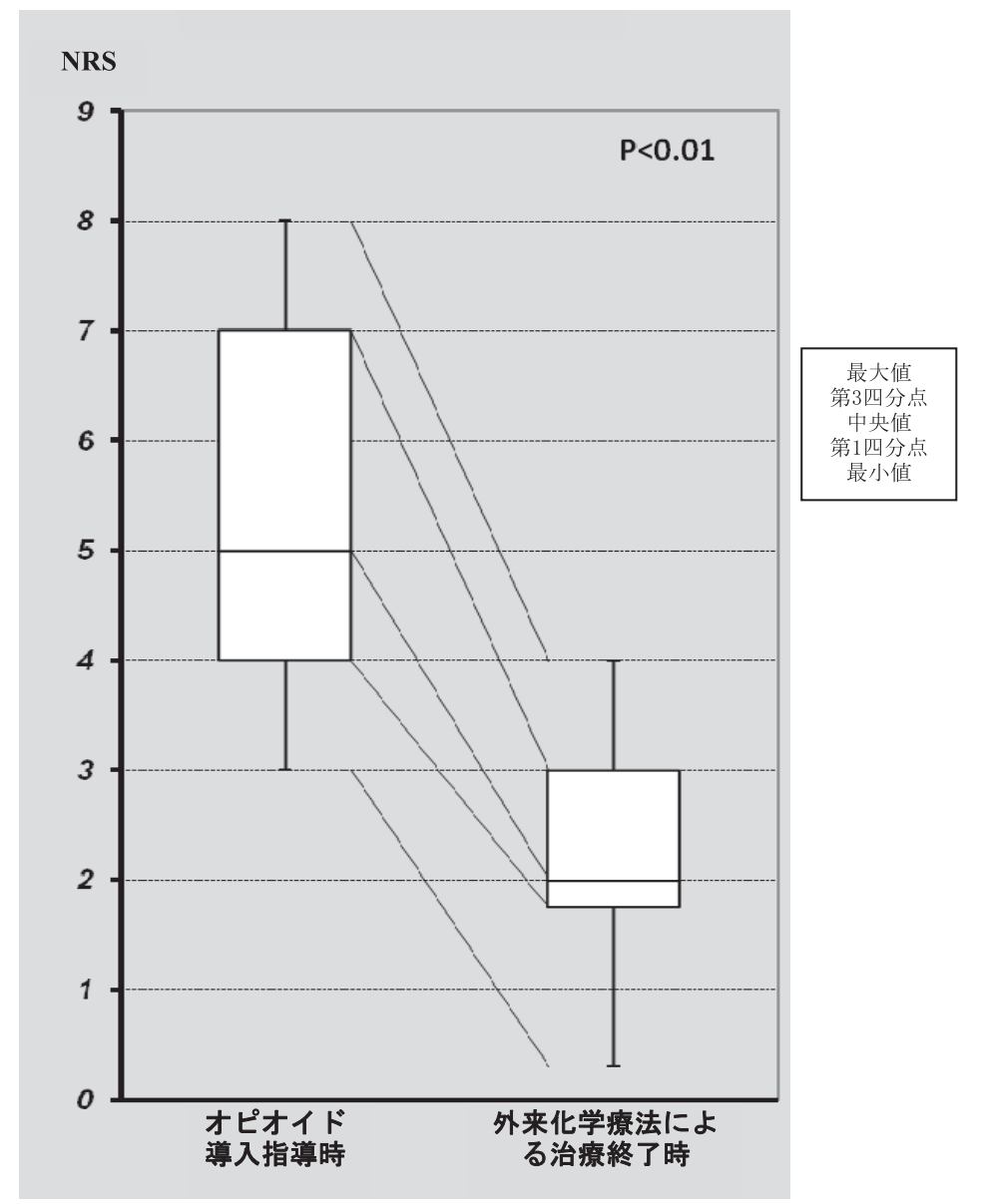

図 7 オピオイド導入指導時と外来化学療法による治療終了時の NRS の変動

が挙げられる，外来診療では入院患者と異なり， 細やかな疼痛評価や患者支援が困難である。 そこ で今回，電話を用いた患者支援を試みた。電話を 用いた支援の患者の受け入れは良好であり，副作 用対策や鎮痛状況に応じたレスキュー薬の服用方 法の指導など，患者帰宅後のサポートを手厚くす ることができた． 2 点目として服薬アドヒアラン ス不良患者への介入が挙げられる，具体的な対応 として，処方薬の理解が得られるまで複数回にわ たる服薬指導の実施，キーパーソンとなる家族を 含めた服薬指導, オピオイド以外の薬剤を 1 包化 することによる処方薬自己管理簡便化の提案，早 期オピオイド導入の有用性の説明，オピオイドと 覚せい郕の違いの説明等を行った。これらの薬剤 師の介入により服薬アドヒアランスが向上し, NRS 減少の一因になったと考える.

一方，医療スタッフに対しては業務件数の推移 および鎮痛薬処方における追加処方提案の割合を 用いて検討を行った。今回の調査において，オピ
オイド導入指導および疼痛管理件数およびオピオ イドローテーション等が必要な疼痛管理困難症例 に対する処方設計依頼件数は経時的に増加してい た。これらの要因として，薬片師によるオピオイ ド導入指導および疼痛管理に対し，他職種スタッ フにおいて理解と評価が得られたためであると考 えられる，追加処方提案に関して，薬剤師介入当 初は嘔気・嘔吐および便秘対策が十分にされてお らず追加処方を依頼することが多かったが, 経時 的に減少してきた。これは処方医へのオピオイド とその副作用に対する薬剤情報提供が効果的に行 えたことを意味していると考える。また，緩和ケ アチームの薬剂師がオピオイド指導を通じて早期 からの緩和ケアを提供することは，がん治療が終 了し完全に Best Supportive Care に移行してからも 継続的な対応が可能であり, 患者との信頼関係が 築きやすいという副次的な効果も期待できる. が ん患者は治療終了を告げられるときにおいてもが んの告知を受けたときと同様に大きな心的ストレ 
スを受けると考えられ, 否認・苦痛・抑うつなど の様々な精神反応を示すことが明らかとなってい $3^{4)}$. 精神的なサポートの観点からも外来化学療 法から緩和ケアまで同じスタッフが，患者を一貫 して支え続けられる意義は大きいと考える.

現在, 薬剤師による外来での服薬指導に保険点 数が認められていないこともあり充実した人員の 確保が難しく，臨床腫瘍科の患者のみの対応であ る。薬の説明・相談を希望する医療職として薬剤 師がもっとも多くもとめられている ${ }^{5)}$ という報告 や, 薬剤師外来をはじめとした外来部門での薬剤 師の有用性が数多く発表されている ${ }^{6 \sim 7)}$. 今回の 調査によって当院においても薬剤師による外来で の疼痛管理の有用性が明らかになった。今後，が ん化学療法を実施している全ての診療科を対象と したチーム医療の拡大を目標とし, 更なる緩和ケ アの充実に貢献していきたい.

\section{引用文献}

1) Hanks G, “Oxford textbook of palliative medicine”, $4^{\text {th }}$ edition, Oxford University Press, Oxford, 2010, pp. 670 .
2）張替ひとみ, 吉田久博, 片山ひろみ, 住吉美佐江, 地域医療におけるがん疼痛管理に関する実態調 査と問題点の検討, 医療薬学, 2008, 34, 156-164.

3) Temel JS, Greer JA, Muzikansky A, Gallagher ER, Admane S, Jackson VA, Dahlin CM, Blinderman CD, Jacobsen J, Pirl WF, Billings JA, Lynch TJ, Early Palliative Care for Patients with Metastatic Non-Small-Cell Lung Cancer. N Engl J Med, 2010, 363, 733-742.

4) Holland JC, Rowland JH, "Handbook of Psycho oncology”, Oxford University Press, New York, 1990, pp.273-282.

5）小笠原信敬, 和賀信継, 岡田浩司, 千代川千代吉, 佐々木真紀, 大堀久詔, 宇佐美伸, 大貫幸二, 加藤誠之, 望月泉, 外来化学療法における薬剤師 による患者支援の有用性に関するアンケート調 査, 癌と化学療法, 2009, 36, 1119-1123.

6）今村牧夫, 名倉弘哲, 武本千恵, 外来がん患者に 対する薬剂師外来の有用性の検討, 医療薬学, 2010, 36, 85-98.

7）祝千佳子, 小林政彦, 寺田智祐, 矢野育子, 松本繁巳, 柳原一広, 福島雅典, 乾賢一, 外来化学療法部に おけるTS-1服用患者に対する継続的な薬学的管 理一患者教育システムの構築と積極的なファー マシューティカルケアへの取り組み一, 医療薬 学, 2009, 35, 866-874. 